\title{
Long-lived 4-oxo-2-enal-derived apparent lysine Michael adducts are actually the isomeric 4-ketoamides
}

Xiaochun Zhu and Lawrence M. Sayre*

Department of Chemistry, Case Western Reserve University, Cleveland, OH 44106

\section{Supporting Information}
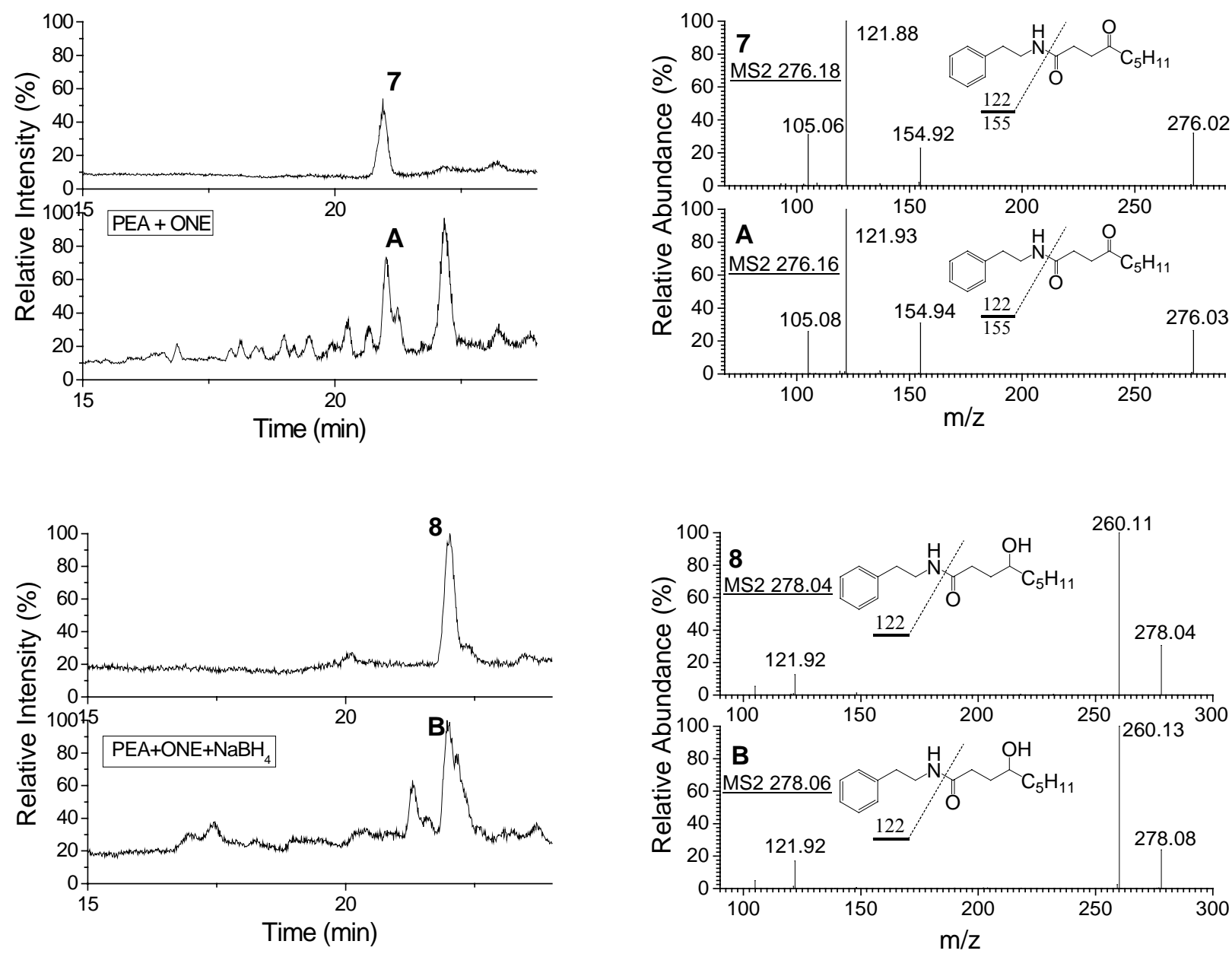

Figure S1. LC-MS chromatograms and tandem mass spectra for the reaction of ONE with phenethylamine for $24 \mathrm{~h}$ (lower panels), without (top) or with (bottom) $\mathrm{NaBH}_{4}$ reduction, and for the authentic phenethylamine derivatives $\mathbf{7}$ and $\mathbf{8}$ (upper panels). 

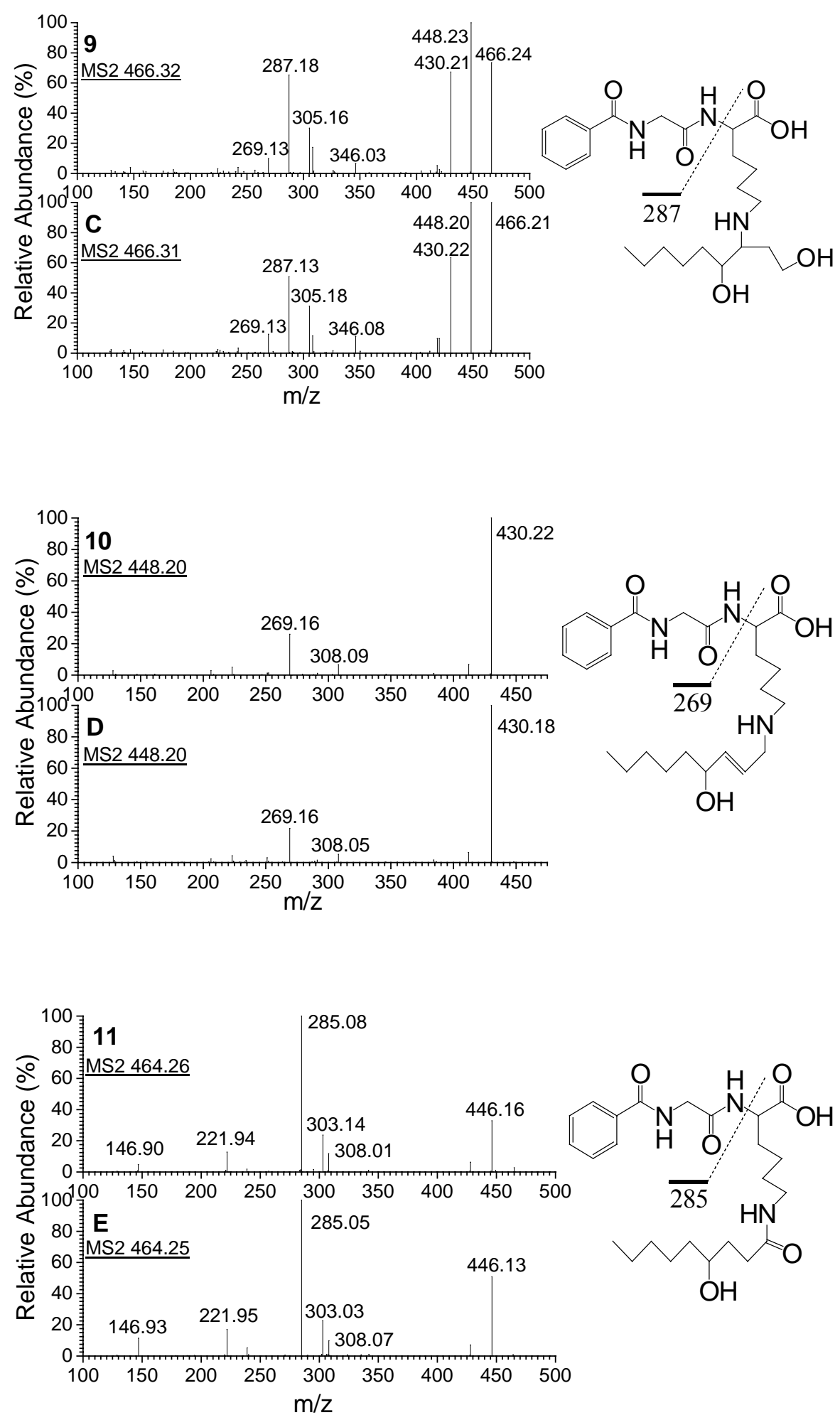

Figure S2. Tandem mass spectra for LC peaks $\mathbf{C}, \mathbf{D}$, and $\mathbf{E}$, observed for the $\mathrm{NaBH}_{4}$-quenched reaction of $N^{\alpha}$-hippuryl-L-lysine with ONE (Figure 1), compared to the tandem mass spectra for authentic reduced Michael adduct 9, reduced Schiff base 10, and reduced 4-ketoamide 11. 


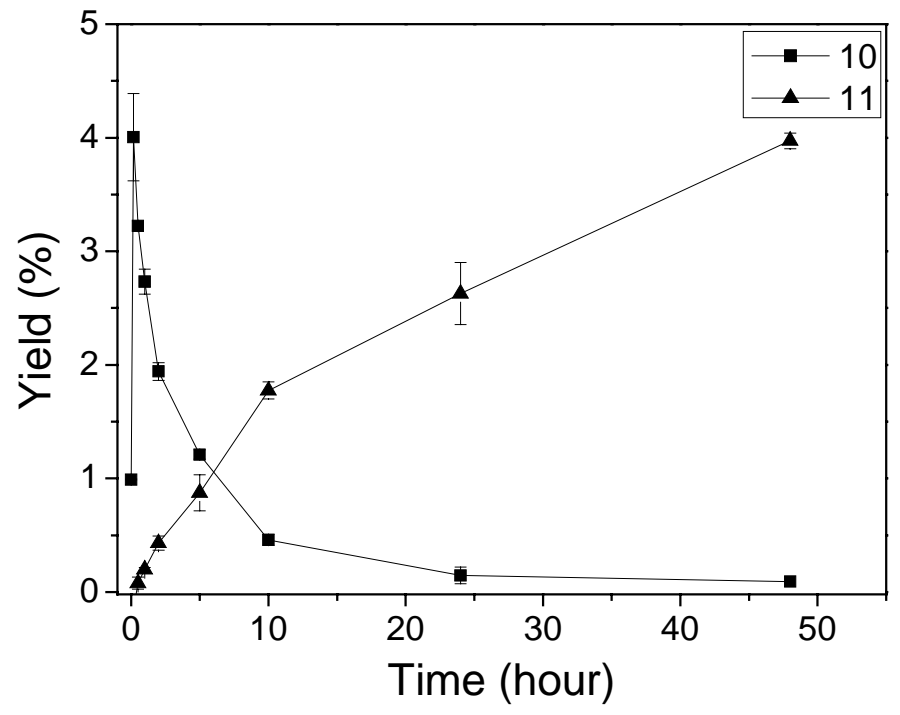

Figure S3. The yield of reduced forms $\mathbf{1 0}$ and $\mathbf{1 1}$ of the Schiff base and 4-ketoamide generated in the reaction of ONE $(0.4 \mathrm{mM})$ and $N^{\alpha}$-hippuryl-L-lysine $(4 \mathrm{mM})$, based on $[\mathrm{ONE}]_{\text {. }}$.

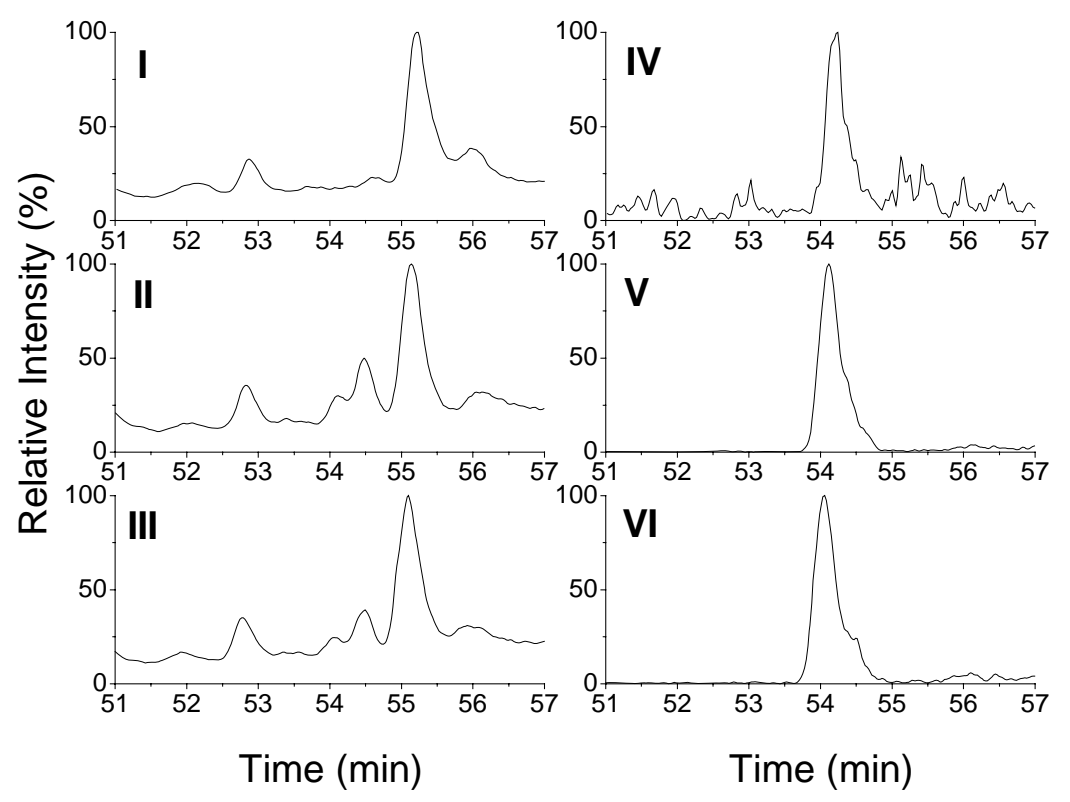

Figure S4. LC-MS/MS confirmation of the identity between the main ONE adduct of $\beta$ lactoglobulin chymotryptic peptide $\mathrm{LQK} * \mathrm{~W}$ and the peptide bearing coupled 4-oxononanoic acid. Panel I shows the TIC for the digest of ONE-modified $\beta$-lactoglobulin, panel III shows the TIC for the digest of 4-oxononanoic acid-coupled $\beta$-lactoglobulin, and panel II shows the TIC for a mixture of the two digests. Panels IV-VI show the reconstructed ion chromatograms $(\mathrm{m} / \mathrm{z} 728.3$, corresponding to the mass of the ONE-adducted peptide) for the same samples I-III, respectively. 


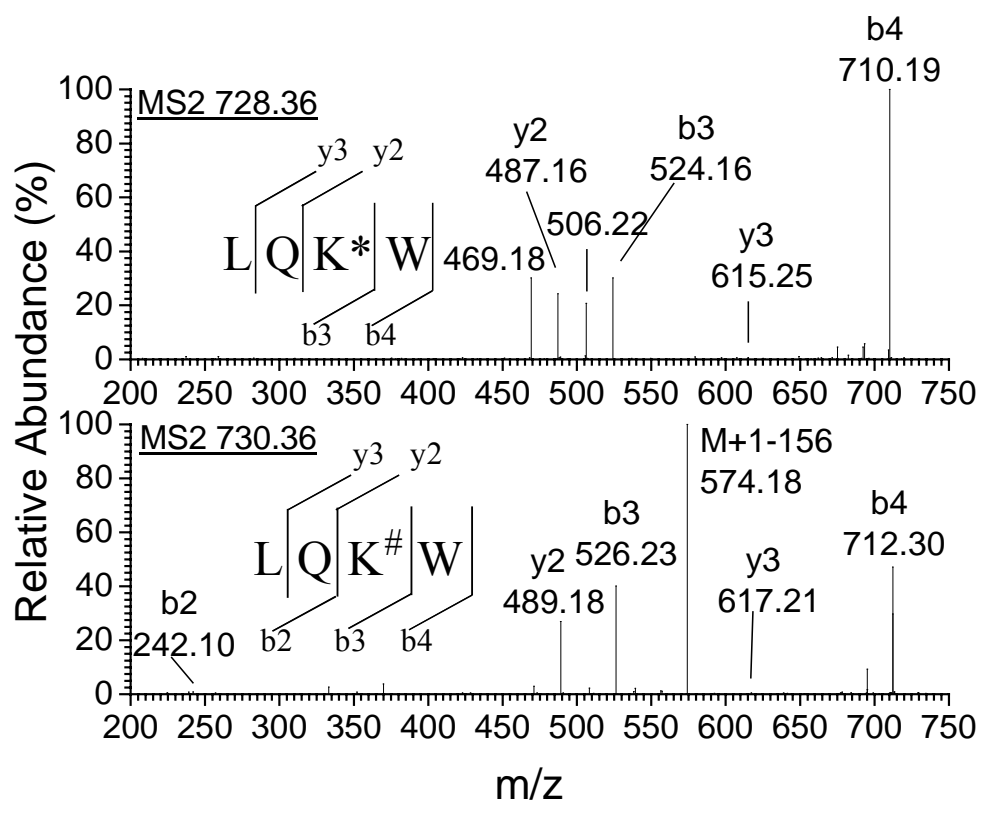

Figure S5. Tandem mass spectra of the singly-charged parent ions following chymotryptic digestion of $\beta$-lactoglobulin coupled with 4-oxononanoic acid, with (lower panel) or without (upper panel) subsequent $\mathrm{NaBH}_{4}$ reduction. * indicates the 4-ketoamide modification. \# indicates the reduced 4-ketoamide modification.

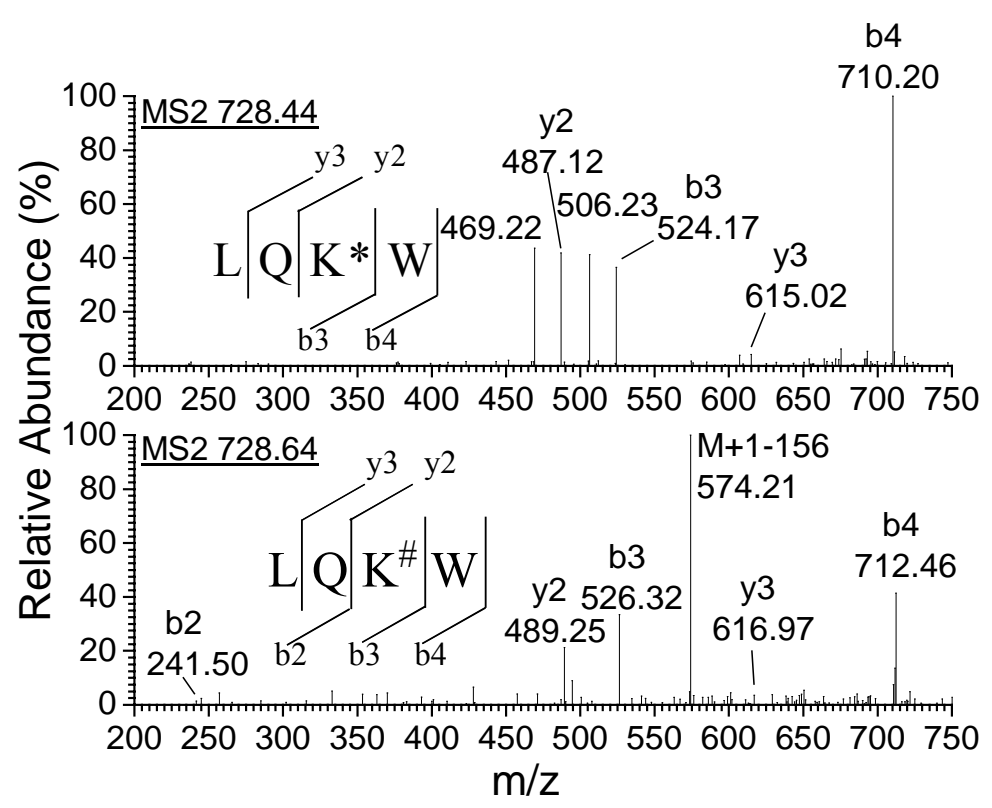

Figure S6. Tandem mass spectra of the singly-charged parent ions for the modified LQKW chymotryptic peptide from the incubation of $\beta$-lactoglobulin with autoxidizing linoleic acid (Fe(II) + ascorbate), with (lower panel) or without (upper panel) subsequent $\mathrm{NaBH}_{4}$ reduction. * indicates the ONE-derived 4-ketoamide modification. \# indicates the reduced 4-ketoamide modification. 
Table S1. ONE-modified or 4-oxononanoic acid (ONA)-coupled $\beta$-lactoglobulin peptides detected by HPLC-ESI-MS/MS in the chymotryptic digest

\begin{tabular}{|l|c|c|c|c|c|}
\hline \multirow{2}{*}{ Peptide sequence } & \multirow{2}{*}{ Position } & \multirow{2}{*}{$\begin{array}{c}\text { Calculated } \\
\text { exact mass }\end{array}$} & \multicolumn{2}{c|}{ Observed mass of the peptide } & \multirow{2}{*}{$\begin{array}{c}\text { Modified } \\
\text { residue }\end{array}$} \\
\cline { 4 - 5 } & & & ONE-modified & ONA-coupled & \\
\hline KGL & $8-10$ & 471.32 & 471.14 & 471.22 & K8 \\
\hline KKY & $100-102$ & 592.37 & 592.38 & 592.44 & K100 \\
\hline KKY & $100-102$ & 592.37 & 592.33 & 592.41 & K101 \\
\hline DKAL & $137-140$ & 600.36 & 600.18 & 600.27 & K138 \\
\hline QKW & $59-61$ & 615.35 & 615.30 & 615.24 & K60 \\
\hline KIDAL & $83-87$ & 713.44 & 713.40 & 713.41 & K83 \\
\hline KALPM & $141-145$ & 713.43 & 713.32 & 713.36 & K141 \\
\hline LQKW & $58-61$ & 728.43 & 728.35 & 728.38 & K60 \\
\hline NENKVL & $88-93$ & 870.49 & 870.36 & 870.42 & K91 \\
\hline DIQKVAGTW & $11-19$ & 1171.64 & 1171.52 & 1171.41 & K14 \\
\hline KIDALNENKVL & $83-91$ & 1410.82 & 1410.78 & 1410.71 & K83 or K91 \\
\hline KGLDIQKVAGTW & $8-19$ & 1469.84 & 1469.48 & 1469.69 & K8 \\
\hline VRTPEVDDEALEKF & $123-136$ & 1801.92 & 1801.81 & 1801.66 & K135 \\
\hline VEELKPTPEGDLEIL & $43-57$ & 1835.99 & 1835.75 & 1835.65 & K47 \\
\hline
\end{tabular}

Table S2. ONE-modified or 4-oxononanoic acid (ONA)-coupled $\beta$-lactoglobulin peptides detected by HPLC-ESI-MS/MS in the chymotryptic digest after $\mathrm{NaBH}_{4}$ reduction.

\begin{tabular}{|l|c|c|c|c|c|}
\hline \multirow{2}{*}{ Peptide sequence } & \multirow{2}{*}{ Position } & \multirow{2}{*}{$\begin{array}{c}\text { Calculated } \\
\text { exact mass }\end{array}$} & \multicolumn{2}{c|}{ Observed mass of the peptide } & \multirow{2}{*}{$\begin{array}{c}\text { Modified } \\
\text { residue }\end{array}$} \\
\cline { 4 - 5 } & & & ONE-modified & ONA-coupled & \\
\hline KKY & $100-102$ & 594.39 & 594.34 & 594.39 & K100 \\
\hline KKY & $100-102$ & 594.39 & 594.34 & 594.40 & K101 \\
\hline DKAL & $137-140$ & 602.38 & 602.27 & 602.32 & K138 \\
\hline QKW & $59-61$ & 617.37 & 617.30 & 617.35 & K60 \\
\hline KIDAL & $83-87$ & 715.46 & 715.36 & 715.39 & K83 \\
\hline KALPM & $141-145$ & 715.44 & 715.25 & 715.38 & K141 \\
\hline LQKW & $58-61$ & 730.45 & 730.33 & 730.36 & K60 \\
\hline NENKVL & $88-93$ & 872.51 & 872.32 & 872.39 & K91 \\
\hline DIQKVAGTW & $11-19$ & 1173.65 & 1173.31 & 1173.49 & K14 \\
\hline KIDALNENKVL & $83-91$ & 1412.84 & 1412.65 & 1412.70 & K83 or K91 \\
\hline KGLDIQKVAGTW & $8-19$ & 1471.85 & 1471.48 & 1471.18 & K8 \\
\hline VRTPEVDDEALEKF & $123-136$ & 1803.94 & 1803.76 & 1803.78 & K135 \\
\hline VEELKPTPEGDLEIL & $43-57$ & 1838.00 & 1837.68 & 1837.67 & K47 \\
\hline
\end{tabular}




\section{Additional Methods}

Gradient elution systems for HPLC and HPLC-MS/MS. For HPLC (Figure 2): Eluent A was a mixture of $95 \% \mathrm{H}_{2} \mathrm{O}, 5 \%$ acetonitrile and $0.02 \%$ trifluoroacetic acid (TFA). Eluent $\mathrm{B}$ was a mixture of $5 \% \mathrm{H}_{2} \mathrm{O}, 95 \%$ acetonitrile and $0.02 \%$ TFA. The gradient program was from $100 \% \mathrm{~A}$ to $78 \% \mathrm{~A}$ over $3 \mathrm{~min}, 78 \%$ A to $76 \%$ A over $17 \mathrm{~min}, 76 \%$ to $0 \%$ A over $2 \mathrm{~min}, 0 \%$ A for $3 \mathrm{~min}, 0 \% \mathrm{~A}$ to $100 \%$ A over $2 \mathrm{~min}, 100 \%$ A for $3 \mathrm{~min}$. For HPLC-MS/MS: Eluent A was a mixture of $95 \% \mathrm{H}_{2} \mathrm{O}$, $5 \% \mathrm{MeOH}$ and $0.1 \%$ formic acid. Eluent $\mathrm{B}$ was a mixture of $5 \% \mathrm{H}_{2} \mathrm{O}, 95 \% \mathrm{MeOH}$ and $0.1 \%$ formic acid. The gradient program for the model reaction mixture (Figures 1 and $\mathrm{S} 1$ ) was from $100 \% \mathrm{~A}$ to $15 \%$ A over $5 \mathrm{~min}, 15 \%$ A to $0 \%$ A over $5 \mathrm{~min}, 0 \%$ A for $20 \mathrm{~min}, 0 \%$ A to $15 \%$ A over $5 \mathrm{~min}, 15 \%$ A to $100 \%$ A over $3 \mathrm{~min}, 100 \% \mathrm{~A}$ for $4 \mathrm{~min}$. The gradient program for the proteolytic digests (Figures S4) was from $80 \%$ A to $20 \%$ A over $72 \mathrm{~min}, 20 \%$ A to $80 \%$ A over 8 min.

Preparation of 4-Oxononanoic Acid. According to a modification of the published procedure, ${ }^{1} \gamma$ nonanoic lactone $(25.0 \mathrm{~g}, 155.2 \mathrm{mmol})$ was added to a magnetically stirred aqueous solution of sodium hydroxide $(6.20 \mathrm{~g}, 155.2 \mathrm{mmol})$ in $40 \mathrm{~mL}$ water in a $250 \mathrm{~mL}$ two-neck flask. After $15 \mathrm{~min}$, the solution was monitored with a $\mathrm{pH}$ meter and $50 \%(\mathrm{w} / \mathrm{w})$ sulfuric acid was added dropwise with cooling by a $0{ }^{\circ} \mathrm{C}$ ice-water bath until the $\mathrm{pH}$ dropped to 6.44 . Then bromine $(24.8 \mathrm{~g}, 155.2 \mathrm{mmol})$ was added dropwise with an addition funnel over $20 \mathrm{~min}$ at $0{ }^{\circ} \mathrm{C}$, and the $\mathrm{pH}$ was maintained between 6.0 and 6.5 by addition of $10 \mathrm{M}$ sodium hydroxide aqueous solution. The $\mathrm{pH}$ of the yellow mixture was reduced to 1.5 by addition of $50 \%$ sulfuric acid. During this course, the mixture became viscous, and water was added until the stir bar could rotate. The reaction mixture was then extracted by ethyl acetate three times $(3 \times 200 \mathrm{~mL})$. The combined organic layer was washed with brine twice, and evaporated to dryness. The residue was recrystallized from hexanes, and the crystalline product was filtered, washed by cold hexanes, and dried. This afforded the title compound as a white crystalline solid (23.72 g, 88.7\%): m.p. 67-68 ${ }^{\circ} \mathrm{C} ;{ }^{1} \mathrm{H}$ NMR (400 MHz, $\left.\mathrm{CDCl}_{3}\right) \delta 10.13(\mathrm{~s}, 1 \mathrm{H}), \delta 2.70(\mathrm{t}, 2 \mathrm{H}, J=6.5 \mathrm{~Hz}), \delta 2.62(\mathrm{t}, 2 \mathrm{H}, J=6.1 \mathrm{~Hz}), \delta 2.43(\mathrm{t}, 2 \mathrm{H}, J=7.2$ $\mathrm{Hz}), \delta 1.58$ (quintet, $2 \mathrm{H}, J=7.6 \mathrm{~Hz}), \delta 1.20-1.35(4 \mathrm{H}), \delta 0.87(\mathrm{t}, 3 \mathrm{H}, J=7.0 \mathrm{~Hz}) ;{ }^{13} \mathrm{C} \mathrm{NMR}(100$ $\left.\mathrm{MHz}, \mathrm{CDCl}_{3}\right) \delta 209.33,179.08,42.91,36.94,31.54,28.00,23.70,22.64,14.12$.

Preparation of $\mathrm{N}$-Phenethyl-4-oxononanamide (7). According to a modification of the published procedure, ${ }^{2}$ dicyclohexylcarbodiimide (DCC) $(533.7 \mathrm{mg}, 2.59 \mathrm{mmol})$ was added to a solution of 4oxononanoic acid (445.4 mg, $2.59 \mathrm{mmol}$ ) and phenethyl amine (316.6 mg, $2.59 \mathrm{mmol})$ in methylene chloride $(25 \mathrm{~mL})$. The reaction mixture was stirred at room temperature. After $17 \mathrm{~h}$, a drop of acetic acid was added to the stirring reaction mixture, and the precipitate was removed by filtration. The filtrate was concentrated by rotary evaporation, and the residue was purified by flash chromatography, eluting with (4:1) hexanes-ethyl acetate. This afforded the title compound as a white powder (300 mg, 42.1\%), which was recrystallized from acetone to afford needles: m.p. 85$86{ }^{\circ} \mathrm{C} ;{ }^{1} \mathrm{H}$ NMR $\left(400 \mathrm{MHz}, \mathrm{CDCl}_{3}\right) \delta 7.30(\mathrm{t}, 2 \mathrm{H}, J=14.4 \mathrm{~Hz}), \delta 7.17-7.25(3 \mathrm{H}), \delta 5.69(\mathrm{~s}, 1 \mathrm{H}), \delta$ $3.49(\mathrm{q}, 2 \mathrm{H}, J=6.7 \mathrm{~Hz}), \delta 2.79(\mathrm{t}, 2 \mathrm{H}, J=7.2 \mathrm{~Hz}), \delta 2.74(\mathrm{t}, 2 \mathrm{H}, J=6.4 \mathrm{~Hz}), \delta 2.42(\mathrm{t}, 2 \mathrm{H}, J=7.6$ $\mathrm{Hz}), \delta 2.37(\mathrm{t}, 2 \mathrm{H}, J=6.6 \mathrm{~Hz}), \delta 1.56$ (quintet, $2 \mathrm{H}, J=7.5 \mathrm{~Hz}), \delta 1.20-1.35(4 \mathrm{H}), \delta 0.88(\mathrm{t}, 3 \mathrm{H}, J=$ 
$7.0 \mathrm{~Hz}) ;{ }^{13} \mathrm{C}$ NMR $\left(100 \mathrm{MHz}, \mathrm{CDCl}_{3}\right) \delta 210.54,172.16,139.11,129.00(2 \mathrm{C}), 128.84$ (2C), 126.71, $43.02,40.87,37.88,35.89,31.60 .30 .18,23.73,22.66,14.16$; HRMS (FAB) calcd for $\mathrm{C}_{17} \mathrm{H}_{26} \mathrm{NO}_{2}$ $(\mathrm{MH}+)$ 276.1964, found, 276.1969 .

Preparation of $\mathrm{N}$-Phenethyl-4-hydroxynonanamide (8). According to a modification of the published procedure, ${ }^{3}$ a solution of $\gamma$-nonanoic lactone $(2.09 \mathrm{~g}, 13.0 \mathrm{mmol})$ and phenethylamine $(2.35 \mathrm{~g}, 19.4 \mathrm{mmol})$ in a $30 \mathrm{~mL}$ THF was heated at reflux $\left(76^{\circ} \mathrm{C}\right)$. After $112 \mathrm{~h}$, the reaction mixture was concentrated, and the residue was purified by flash chromatograph, on silica gel, eluting with a gradient from EtOAc-hexanes (1:1) to $100 \%$ EtOAc. This afforded the title compound as a white solid (2.10 g, 58.4\%): m.p.73-74 ${ }^{\circ} \mathrm{C} ;{ }^{1} \mathrm{H}$ NMR $\left(200 \mathrm{MHz}, \mathrm{CDCl}_{3}\right) \delta 7.18-7.35(5 \mathrm{H}), \delta 5.89(\mathrm{~s}, 1 \mathrm{H})$, $\delta 3.43-3.60(3 \mathrm{H}), \delta 2.93(\mathrm{~s}, 1 \mathrm{H}), \delta 2.80(\mathrm{t}, 2 \mathrm{H}, J=7.1 \mathrm{~Hz}), \delta 2.29(\mathrm{t}, 2 \mathrm{H}, J=6.4 \mathrm{~Hz}), \delta 1.79(\mathrm{~m}$, $1 \mathrm{H}), \delta 1.64(\mathrm{~m}, 1 \mathrm{H}), \delta 1.20-1.45(8 \mathrm{H}), \delta 0.89(\mathrm{t}, 3 \mathrm{H}, J=7.5 \mathrm{~Hz}) ;{ }^{13} \mathrm{C} \mathrm{NMR}\left(50 \mathrm{MHz}, \mathrm{CDCl}_{3}\right) \delta$ 173.81, 138.91, 128.81 (2C), 128.68 (2C), 126.58, 71.39, 40.71, 37.75, 35.64, 33.29, 32.59, 31.94, $25.44,22.69,14.11$.

Incubation of Phenethylamine with ONE. A solution of phenethyl amine $(50 \mathrm{mM}, 100 \mu \mathrm{L})$ in $\mathrm{pH}$ 7.4 HEPES buffer $(100 \mathrm{mM}, 1.60 \mathrm{~mL})$ was incubated with a solution of ONE in EtOH $(13.3 \mathrm{mM}$, $300 \mu \mathrm{L}$ ) at $37^{\circ} \mathrm{C}$. After $24 \mathrm{~h}$, the solution was stored at $-20^{\circ} \mathrm{C}$ for LC-MS analysis.

Incubation of Phenethylamine with ONE Followed by Quenching with Sodium Borohydride. A solution of phenethyl amine in $\mathrm{EtOH}(40 \mathrm{mM}, 100 \mu \mathrm{L})$ diluted with $\mathrm{pH} 7.4$ sodium phosphate buffer $(100 \mathrm{mM}, 800 \mu \mathrm{L})$, was incubated with ONE in EtOH $(20 \mathrm{mM}, 100 \mu \mathrm{L})$ at $37^{\circ} \mathrm{C}$. After $24 \mathrm{~h}$, the incubation was quenched by the addition of $\mathrm{NaBH}_{4}(4 \mathrm{mg})$.

\section{Incubation of $\boldsymbol{N}^{\alpha}$-Hippuryl-L-lysine (Hip-Lys) with ONE Followed by Quenching with} Sodium Borohydride. A solution of Hip-Lys $(40 \mathrm{mM}, 1.00 \mathrm{~mL})$ in $\mathrm{pH} 7.4$ sodium phosphate buffer $(100 \mathrm{mM}, 8.00 \mathrm{~mL})$ was incubated with $\mathrm{ONE}$ in EtOH $(20 \mathrm{mM}$ or $4 \mathrm{mM}, 1.00 \mathrm{~mL})$ at $37^{\circ} \mathrm{C}$. After 0,10 , and $30 \mathrm{~min}$, and 1, 2, 5, 10, 24 and $48 \mathrm{~h}, 1.00 \mathrm{~mL}$ aliquots were quenched by the addition of $\mathrm{NaBH}_{4}$ ( $5 \mathrm{mg}$ or $2.5 \mathrm{mg}$, depending on the amount of ONE amount used).

\section{Preparation of 2-(2-Benzamidoacetamido)-6-(1,4-dihydroxynonan-3-ylamino)hexanoic Acid} (9). A solution of HNE $(62.4 \mathrm{mg}, 0.4 \mathrm{mmol})$ in $10 \mathrm{~mL} 5 \%(\mathrm{v} / \mathrm{v})$ EtOH sodium phosphate buffer (pH $7.4,0.1 \mathrm{M})$ was added Hip-Lys $(153.7 \mathrm{mg}, 0.5 \mathrm{mmol})$. The mixture was vortexed and incubated at $37^{\circ} \mathrm{C}$. After $7 \mathrm{~h}$, sodium borohydride $(121.6 \mathrm{mg}, 3.2 \mathrm{mmol})$ was added and the resulting mixture was stirred overnight. The $\mathrm{pH}$ of the mixture was adjusted to 8 with $2 \mathrm{~N} \mathrm{HCl}$, and then concentrated by rotary evaporation. The residue was applied to a $1.0 \mathrm{~mm}$ preparative silica gel TLC plate, eluting with $(6 / 1 / 1, \mathrm{v} / \mathrm{v} / \mathrm{v}) n$-butanol/water/acetic acid. This afforded the title compound as a white solid. ${ }^{1} \mathrm{H}$ NMR (400 MHz, CD 30 OD) $\delta 7.91(\mathrm{~d}, 2 \mathrm{H}, J=6.0 \mathrm{~Hz}), \delta 7.56(\mathrm{t}, 1 \mathrm{H}, J=7.2 \mathrm{~Hz}), \delta 7.48(\mathrm{t}, 2 \mathrm{H}, J=$ $7.4 \mathrm{~Hz}$ ), $\delta 4.35$ (broad, 1H), $\delta 3.98-4.16(2 \mathrm{H}), \delta 3 . .91$ (broad, 1H), $\delta 3.80$ (broad, $1 \mathrm{H}), \delta 3.73$ (broad, 1H), $\delta 3.27$ (broad, 1H), $\delta 3.06$ (broad, 2H), $\delta 1.88$ (broad, 2H), $\delta 1.71$ (broad, 2H), $\delta$ $1.20-1.60(12 \mathrm{H}), \delta 0.91(\mathrm{t}, 3 \mathrm{H}, J=6.4)$; HRMS (FAB) calcd for $\mathrm{C}_{24} \mathrm{H}_{40} \mathrm{~N}_{3} \mathrm{O}_{6}(\mathrm{MH}+) 466.2917$, found, 466.2922 . 


\section{Preparation of (E)-2-(2-Benzamidoacetamido)-6-(4-hydroxynon-2-enylamino)hexanoic Acid}

(10). A solution of Hip-Lys (53.64 mg, $0.17 \mathrm{mmol})$ in $3 \mathrm{~mL}$ of water was adjusted to $\mathrm{pH} 12$ with concentrated aqueous $\mathrm{NaOH}$. To the solution was added ONE $(21.5 \mathrm{mg}, 0.14 \mathrm{mmol})$ in $2 \mathrm{~mL}$ of acetonitrile. The $\mathrm{pH}$ of the mixture was adjusted to 9 with aqueous $\mathrm{NaOH}$. After stirring for $20 \mathrm{~min}$ at room temperature, sodium borohydride $(53.0 \mathrm{mg}, 1.40 \mathrm{mmol})$ was added, and the resulting mixture was stirred for $2 \mathrm{~h}$., and then concentrated by rotary evaporation. The residue was applied to a $1.0 \mathrm{~mm}$ preparative silica gel TLC plate, eluting with $(6 / 1 / 1, \mathrm{v} / \mathrm{v} / \mathrm{v}) n$-butanol/water/acetic acid. This afforded the title compound as a white solid. ${ }^{1} \mathrm{H} \mathrm{NMR}\left(400 \mathrm{MHz}, \mathrm{CD}_{3} \mathrm{OD}\right) \delta 7.90(\mathrm{~d}, 2 \mathrm{H}, J=$ $7.2 \mathrm{~Hz}), \delta 7.56(\mathrm{t}, 1 \mathrm{H}, J=7.2 \mathrm{~Hz}), \delta 7.48(\mathrm{t}, 2 \mathrm{H}, J=7.6 \mathrm{~Hz}), \delta 5.96(\mathrm{dd}, 1 \mathrm{H}, J=15.4,5.8 \mathrm{~Hz}), \delta$ $5.72(\mathrm{dt}, 1 \mathrm{H}, J=15.2,6.8 \mathrm{~Hz}), \delta 4.28(\mathrm{dd}, 1 \mathrm{H}, J=6.8,4.8 \mathrm{~Hz}), \delta 4.01-4.11(3 \mathrm{H}), \delta 3.59(\mathrm{~d}, 2 \mathrm{H}, J=$ $6.8 \mathrm{~Hz}), \delta 2.93(\mathrm{t}, 2 \mathrm{H}, J=7.4 \mathrm{~Hz}), \delta 1.60-1.76(3 \mathrm{H}), \delta 1.24-1.53(11 \mathrm{H}), \delta 0.90(\mathrm{t}, 3 \mathrm{H}, J=6.8 \mathrm{~Hz})$. HRMS (FAB) calcd for $\mathrm{C}_{24} \mathrm{H}_{38} \mathrm{~N}_{3} \mathrm{O}_{5}(\mathrm{MH}+)$ 448.2811, found, 448.2821.

\section{Preparation of 2-(2-Benzamidoacetamido)-6-(4-hydroxynonanamido)hexanoic Acid (11). A} solution of 4-oxononanoic acid $(172.2 \mathrm{mg}, 1.0 \mathrm{mmol})$ and $N$-hydroxysuccinimide $(115.8 \mathrm{mg}, 1.0$ $\mathrm{mmol})$ in $10 \mathrm{~mL}$ of anhydrous THF was stirred at $0{ }^{\circ} \mathrm{C}$. After $5 \mathrm{~min}$, a solution of DCC (206.3 $\mathrm{mg}$, $1.0 \mathrm{mmol}$ ) in $5 \mathrm{~mL}$ of anhydrous THF was added dropwise over a period of $5 \mathrm{~min}$. The reaction mixture was stirred at room temperature for $3 \mathrm{~h}$. The white precipitate was removed by filtration, and the filtrate was added into a solution of Hip-Lys $(276.6 \mathrm{mg}, 0.9 \mathrm{mmol})$ in $10 \mathrm{~mL}$ of bicine buffer $(0.5 \mathrm{M}, \mathrm{pH} 9.0)$ at $0{ }^{\circ} \mathrm{C}$ under argon. The reaction mixture was stirred at room temperature for $4.5 \mathrm{~h}$. Sodium borohydride $(380.6 \mathrm{mg}, 10.0 \mathrm{mmol})$ was added, with stirring overnight. The mixture was acidified to $\mathrm{pH} 2$ with $2 \mathrm{~N} \mathrm{HCl}$ and extracted by ethyl acetate $(2 \times 30 \mathrm{~mL})$. The combined organic layer was washed twice with $\mathrm{pH} 1-2$ water and finally with brine. The residue obtained upon rotary evaporation was subjected to silica gel flash chromatography, eluting first with ethyl acetate only and then with ethyl acetate-methanol (1:1). This afforded the title compound as a white solid (240 mg, 57.5\%). ${ }^{1} \mathrm{H}$ NMR (400 MHz, CD $\left.{ }_{3} \mathrm{OD}\right) \delta 7.89$ (d, 2H, J=7.2 Hz), $\delta 7.55$ (t, $1 \mathrm{H}, J=7.4 \mathrm{~Hz}), \delta 7.47(\mathrm{t}, 2 \mathrm{H}, J=7.4 \mathrm{~Hz}), \delta 4.42(\mathrm{broad}, 1 \mathrm{H}), \delta 4.13(\mathrm{~d}, 1 \mathrm{H}, J=16.4 \mathrm{~Hz}), \delta 4.08$ $(\mathrm{d}, 1 \mathrm{H}, J=16.4 \mathrm{~Hz}), \delta 3.50(\mathrm{~m}, 1 \mathrm{H}), \delta 3.17(\mathrm{t}, 2 \mathrm{H}, J=6.8 \mathrm{~Hz}), \delta 2.31$ (ddd, $1 \mathrm{H}, J=14.4,8.4,6.8$ $\mathrm{Hz}$ ), $\delta 2.27$ (ddd, $1 \mathrm{H}, J=14.8,8.0,6.8 \mathrm{~Hz}), \delta 1.90(\mathrm{~m}, 1 \mathrm{H}), \delta 1.67-1.82(2 \mathrm{H}), \delta 1.21-1.67(13 \mathrm{H}), \delta$ $0.90(\mathrm{t}, 3 \mathrm{H}, J=7.0 \mathrm{~Hz}) ;{ }^{13} \mathrm{C} \mathrm{NMR}\left(150 \mathrm{MHz}, \mathrm{CD}_{3} \mathrm{OD}\right) \delta 174.85,174.45,170.32,169.09,133.64$, 131.58, 128.23 (2C), 127.14 (2C), 70.56, 52.52, 42.63, 38.71, 36.95, 32.96, 32.24, 31.69, 31.03, 28.51, 25.10, 22.73, 22.33, 13.08. HRMS (FAB) calcd for $\mathrm{C}_{24} \mathrm{H}_{38} \mathrm{~N}_{3} \mathrm{O}_{6}(\mathrm{MH}+)$ 464.2761, found, 464.2761 .

Quantification of 9-11. The concentrations of 9-11 were determined by NMR using the residual solvent $\left(\mathrm{CHD}_{2} \mathrm{OD}\right)$ peak as the internal standard, whose concentration was standardized using HipLys. Specifically, $2.1 \mathrm{mg}$ of Hip-Lys $(6.8 \mu \mathrm{mol})$ was dissolved in $665 \mu \mathrm{L}$ of $\mathrm{CD}_{3} \mathrm{OD}(580.6 \mathrm{mg})$ in an NMR tube. The independently prepared compounds 9-11 were individually dissolved in $665 \mu \mathrm{L}$ of the same stock $\mathrm{CD}_{3} \mathrm{OD}$ in NMR tubes. Comparison of the integrals of the residual $\mathrm{CHD}_{2} \mathrm{OD}$ solvent peak vs. the $\mathrm{CH}_{2} \mathrm{CH}_{2} \mathrm{NH}_{2}$ signal of Hip-Lys on one hand and characteristic signals in compounds 9-11 on the other hand, then allowed calculation of the concentrations of the latter. 
Standard curves for the three compounds were then constructed by HPLC using 10, 20, 40, and 80 $\mu \mathrm{M}$ aliquots of the same $\mathrm{CD}_{3} \mathrm{OD}$ solutions of 9-11.

Coupling of 4-Oxononanoic Acid to $\beta$-Lactoglobulin. To a solution of 4-oxononanoic acid (5.0 $\mathrm{mM}, 2.0 \mathrm{~mL}$ ) in MES buffer (pH 6.0, $100 \mathrm{mM}$ ) was added 1-ethyl-3-(3-dimethylaminopropyl)carbodiimide hydrochloride $(2.0 \mathrm{mg}, 10.4 \mu \mathrm{mol})$ and $N$-hydroxysulfosuccinimide $(3.2 \mathrm{mg}, 14.7 \mu \mathrm{mol})$, and the mixture was vortexed for $20 \mathrm{~min}$. A solution of bovine $\beta$-lactoglobulin $(2.0 \mathrm{~mL}, 2.0 \mathrm{mg} / \mathrm{mL})$ in sodium phosphate buffer $(\mathrm{pH} 8.0,200 \mathrm{mM})$ was then added. After $6 \mathrm{~h}$ of vortex-mixing, a $2 \mathrm{~mL}$ aliquot was treated with $19 \mathrm{mg}$ of $\mathrm{NaBH}_{4}$ at $25^{\circ} \mathrm{C}$ overnight. The other $2 \mathrm{~mL}$ of reaction mixture was vortex-mixed overnight. Both solutions were then applied to PD-10 columns, eluting with 3.5 $\mathrm{mL}$ of doubly distilled $\mathrm{H}_{2} \mathrm{O}$. The eluates were concentrated to dryness prior to proteolytic digestion.

\section{References}

1. Wineburg, J. P., Abrams, C., and Swern, D. (1975) Improved preparation and characterization of unsaturated $\gamma$-lactones. J. Het. Chem., 12, 749-754.

2. Irikawa, H., Toyoda, Y., Kumagai, H., and Okumura, Y. (1989) Isolation of four 2,3,5,6,11,11bhexahydro-3-oxo- $1 \mathrm{H}$-indolizino[8,7-b]indole-5-carboxylic acids from Clerodendron Trichotomum Thunb and properties of their derivatives. Bull. Chem. Soc. Jpn. 62, 880-887.

3. Lee, Y. S., Kang, S. S., Choi, J. H., and Park, H. (1997) Asymmetric synthesis of functionalized benzo[a]quinolizine derivatives via a diastereoselective $N$-acyliminium ion cyclization. Tetrahedron, 53, 3045-3056. 